Julian M. J. Ward

Cedara Agricultural Development Inst., Pietermaritzburg, South Africa

Erik L. Stromberg

Virginia Polytechnic Institute and State University, Blacksburg

David C. Nowell

PANNAR Seed (PTY) Limited, Graytown, South Africa

Forrest W. Nutter, Jr.

lowa State University, Ames

\title{
Gray Leaf Spot \\ A Disease of Global Importance in Maize Production
}

Gray leaf spot of maize (Zea mays), caused by Cercospora zeae-maydis (68), has more than lived up to the 1983 prediction of Latterell and Rossi as a disease on the move (34). Sometimes referred to as a "government-made disease" because reduced tillage resulting from federal incentives contributed to its proliferation, gray leaf spot has continued to expand its geographic distribution and increase in intensity over the past 25 years. Gray leaf spot is now recognized as one of the most significant yield-limiting diseases of maize (corn) worldwide $(38,43,79)$. It now poses a serious threat to maize production in many areas of the eastern United States and, more recently, in large areas of the U.S. Corn Belt and Africa (38,4244,52,73,80). In August 1995, the Wall Street Journal reported yield losses due to gray leaf spot as high as $50 \%$ in some U.S. maize fields (72). Garst Seeds estimates that gray leaf spot has damaged as much as 9.3 million ha of maize in Iowa, Illinois, Indiana, Ohio, Kentucky, and Tennessee, and that an additional 11.3 million ha in other areas of the United States could potentially be affected (25). They estimate that gray leaf spot is increasing in extent at a rate of 80 to $160 \mathrm{~km}$ each year, and the

Corresponding authors: Forrest W. Nutter, Jr., E-mail: fwn@iastate.edu, and Julian M. J. Ward, E-mail: jward@cedara1.agric.za

Publication no. D-1999-0723-01F

(C) 1999 The American Phytopathological Society disease is now endemic throughout much of the midwestern Corn Belt.

In Africa, gray leaf spot has become pandemic $(42,73)$. The occurrence of the pathogen in the Province of KwaZulu-Natal, South Africa, was the first official report from the African continent. Extensive areas of farmland currently under maize production in other geographical areas of Africa are potentially at risk, should the pathogen be introduced and environmental conditions be favorable to gray leaf spot development.

In addition to the United States and Africa, gray leaf spot has been reported in Brazil, Columbia, Peru, Trinidad, Costa Rica, Mexico, and Venezuela $(8,12,34)$. It has also recently been recognized as a yield-limiting disease of maize in China (15), particularly in the Jilin Province (D. G. White, personal communication).

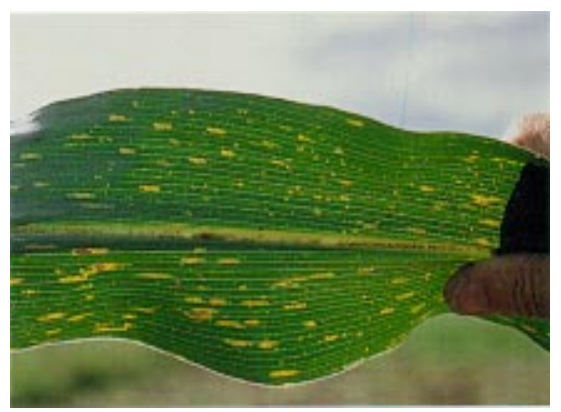

Fig. 1. Immature gray leaf spot lesions on maize leaf appear as small tan spots, often with chlorotic borders.

\section{Symptoms}

Symptoms are typically first observed on the lower leaves. Initially, immature lesions are not easily distinguished from lesions caused by other foliar pathogens of maize (61). Lesions first appear as small tan spots, about 1 to $3 \mathrm{~mm}$ long, that are rectangular to irregular in shape. These

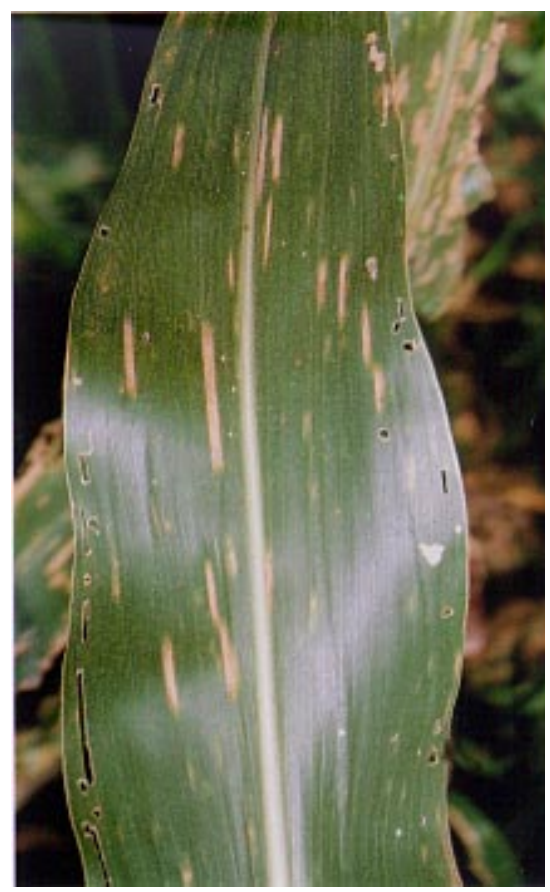

Fig. 2. Mature gray leaf spot lesions on maize leaf are gray to tan in color and distinctly rectangular in shape. 
spots usually have chlorotic borders that are more easily observed when diseased leaves are viewed through transmitted light (Fig. 1). Mature gray leaf spot lesions, however, are readily distinguished from other foliar diseases of maize; they are gray to tan in color and are distinctly rectangular in shape (5 to $70 \mathrm{~mm}$ long by 2 to $4 \mathrm{~mm}$ wide) (Fig. 2). A distinguishing feature of gray leaf spot is that lesions typically run parallel with leaf veins $(4,61)$. Further lesion expansion results in the coalescing of lesions and the blighting of entire leaves (Fig. 3). With severe blighting, stalk deterioration and severe lodging may occur (61). Sporulating lesions assume a grayish cast, hence the name gray leaf spot $(4,34)$. The latent period for gray leaf spot is long in comparison to other foliar pathogens and can take as long as 14 to 28 days after infection for lesions to sporulate $(6,61)$. Lesion size, number, and type can vary greatly among genotypes. Susceptible inbreds and hybrids commonly display numerous necrotic lesions $(29,36,37)$, while moderately resistant inbreds and hybrids often exhibit chlorotic and/or fleck-type lesions (5,56) (Fig. 4).

\section{History}

Importance of gray leaf spot in the United States. C. zeae-maydis was first identified from specimens collected in 1924 by Tehon and Daniels in Alexander County, in southern Illinois near the Mississippi River. This is generally regarded as the first documented report of C. zeaemaydis in the United States. Specimens were originally sent to Charles Chupp at Cornell University, Ithaca, New York, who identified the pathogen as Cercospora

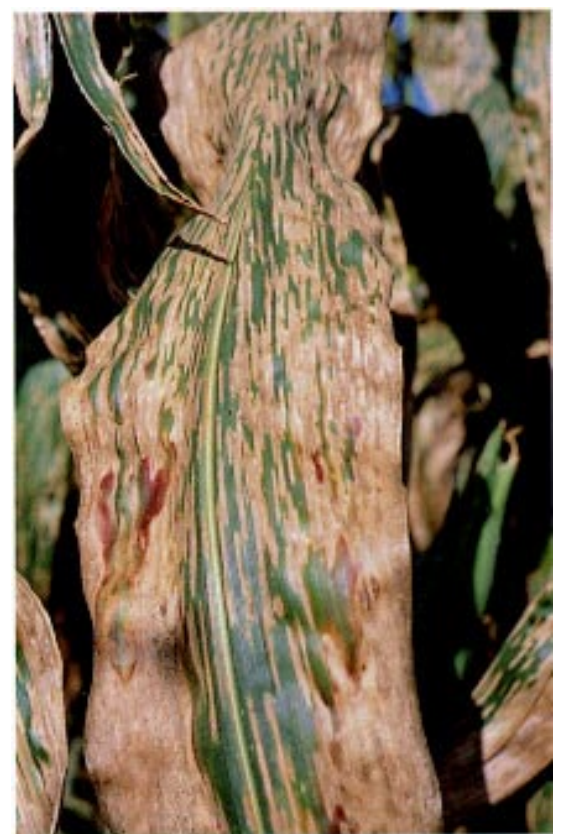

Fig. 3. When severe epidemics of gray leaf spot occur in maize, lesions may coalesce and blight the entire leaf. zeae-maydis. Chupp would later report the first occurrence of gray leaf spot in South America (12).

The next report documenting the presence of gray leaf spot in the United States was published in 1943 by R. A. Hyre (30). In a survey of maize diseases in Tennessee and Kentucky, Hyre reported that gray leaf spot severities (diseased leaf area/total leaf area $\times 100$ ) in two counties in Tennessee were $20 \%$ and $>90 \%$, respectively. In Kentucky, he reported gray leaf spot-infested maize fields in three counties, with gray leaf spot severities ranging from 18 to $45 \%, 20$ to $25 \%$, and 4 to $10 \%$ in the three counties (30). Although yield data were not obtained, this survey was the first to quantitatively document the devastating potential of gray leaf spot in reducing photosynthetic (green) leaf area.

Seven years later, Roane reported the occurrence of gray leaf spot during the 1949 and 1950 growing seasons in Blacksburg, Virginia (54). He noted that gray leaf spot was a relatively unimportant, lateseason disease of maize in most fields; however, severe disease levels were observed at higher altitudes (500 to $1,000 \mathrm{~m}$ above sea level). Roane was also the first to evaluate maize inbreds for resistance to gray leaf spot. Although he observed different levels of gray leaf spot severity among inbred lines, double crossing experiments involving genotypes with lower levels of disease did not result in hybrids with higher levels of gray leaf spot resistance. Roane reported that gray leaf spot resulted in the "complete destruction" of these genotypes in field tests.

It was not until 1963 that the next report of gray leaf spot in the United States was published (33). Kingsland reported that gray leaf spot incidence (number of diseased plants/total number of plants assessed $\times 100)$ was $100 \%$ in western South Caro- lina and that gray leaf spot severity exceeded $80 \%$ of the total leaf area in affected fields. Boothroyd (8) reported the occurrence of gray leaf spot in Costa Rica and speculated that this disease was favored by warm temperatures, moderately high relative humidities, and/or extended periods of dew.

Prior to 1972, C. zeae-maydis was not considered to be economically important in the mountainous regions of North Carolina. Following the epidemic years of 1972 and 1973, however, gray leaf spot was reported by K. J. Leonard to be "the most destructive foliar disease" of maize (35). In severely affected fields, Leonard reported that most of the maize foliage had been killed by mid-August. Leonard also speculated that gray leaf spot epidemics were probably associated with moderate temperatures, abundant rainfall, high light intensity, and/or relatively large diurnal fluctuations in temperature and humidity in the mountainous regions.

Gray leaf spot remained a relatively obscure and sporadic disease in Virginia until 1971 (59) but has become increasingly prevalent since then. The increase in gray leaf spot prevalence and severity in Virginia over the past 18 years has been attributed to the increased adoption of both reduced-tillage and continuous maize cropping systems (59). By the early 1980s, Stromberg and Donahue (64) had begun assessing the performance of hybrids in field tests under severe, naturally occurring gray leaf spot epidemics. They found that almost all of the hybrids available for testing, mainly those originating from breeding programs in the Corn Belt, were highly to moderately susceptible to gray leaf spot and that grain yields were severely depressed by gray leaf spot epidemics in Virginia (64). They predicted that gray leaf spot would become an im-

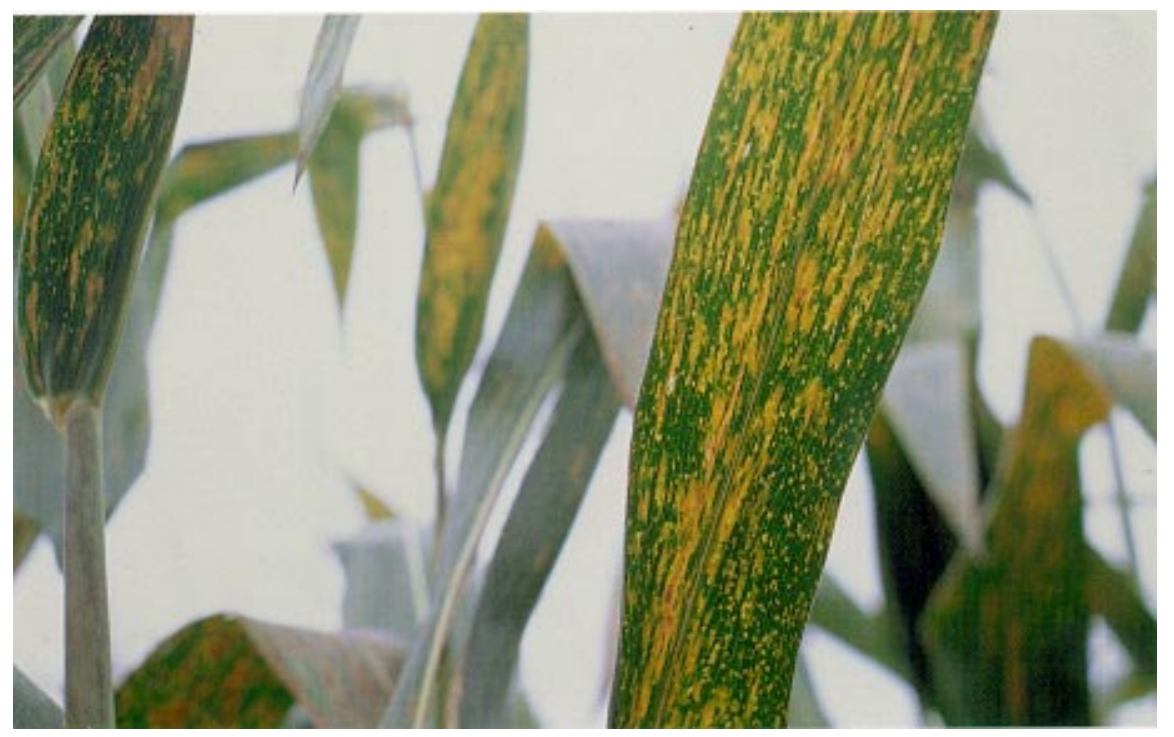

Fig. 4. Chlorotic, fleck-type lesions of gray leaf spot exhibited by some moderately resistant maize hybrids. 


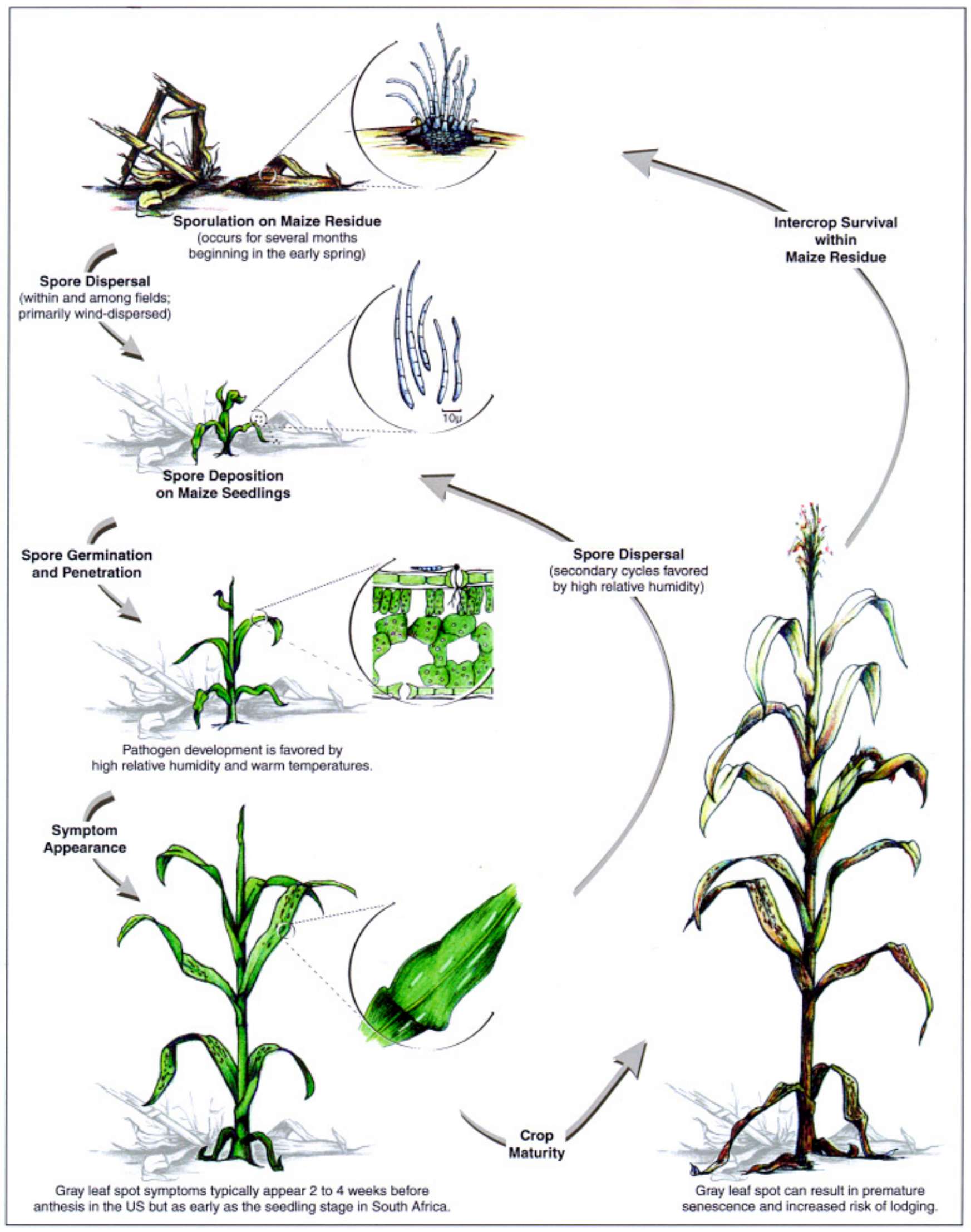

Fig. 5. Disease cycle of gray leaf spot in maize. 
portant yield-limiting disease in other maize-growing regions of the United States in response to the advent of reduced- or notillage maize production systems, which would increase inoculum levels over time. From 1988 to 1995 , there was a dramatic increase in the prevalence and severity of gray leaf spot in the Corn Belt, as far west as eastern Colorado, Kansas, and Nebraska in fields under irrigation, as well as in nonirrigated fields as far north as Wisconsin and Minnesota (38).

Importance of gray leaf spot in Africa. Although rapid expansion in the geographic distribution of gray leaf spot on the African continent has already caused severe reductions in grain yield and quality, this disease poses serious repercussions concerning the food security and nutrition of African nations. This is because maize is the major food staple for most of the indigenous, rural populations in Africa (13). Africans consume nearly one-fourth of the total feed (livestock) maize produced in Africa, and for many countries, the per capita consumption of maize may be as high as $100 \mathrm{~kg}$ per year (13). In light of the fact that the production of cereals in Africa has fallen in the past 25 years (13), the impact of gray leaf spot is likely to contribute to a further widening of the food deficits in most African nations.

Since $C$. zeae-maydis was first reported to cause economic losses in South Africa during the 1990 to 1991 growing season, the pathogen has become pandemic throughout the province of KwaZulu-Natal and has spread into the neighboring provinces of Eastern Cape, Free State, Gauteng, Mpumalanga, and the Northern Province $(42,73)$. The pathogen was first detected in Zimbabwe during the 1995 to 1996 season, and gray leaf spot is now recognized as an economically important pathogen in all maize-producing areas of Zimbabwe $(42,73)$. Gray leaf spot is rapidly becoming a yield-limiting disease throughout Zambia as well. South African researchers visiting Cameroon (November 1995), Kenya (November 1995), Uganda (1994), and Zaire (1996) observed severe gray leaf spot epidemics in these countries; however, yield losses associated with the disease have yet to be quantified (42). Gray leaf spot has also been reported in Ethiopia, Malawi, Mozambique, Nigeria, Swaziland, Tanzania, and Zambia $(42,76)$.

Farming systems in South Africa are quite diverse. At one end of the spectrum there are approximately 55,000 commercial farms occupying approximately 3.9 million ha of farmland, on which farmers produce 4 to 9 million metric tons of grain annually (3). These large-scale producers are backed by a sophisticated market infrastructure that helps to stabilize farm income. Gray leaf spot management priorities for these farmers are varied but vital to the continued economic production of maize. In contrast, there are more than a million small-scale subsistence farmers in South Africa, many of whom are women and children. This is because males often leave rural land areas to supplement family incomes by working in urban industries (3). Many of these farmers are illiterate and have insecure land rights under a system of communal land tenure. The impact of gray leaf spot on these small-scale farmers could be devastating, as the disease management options available to these people are very limited and maize accounts for as much as $70 \%$ of their food production (2). Because small-scale farms are usually only 1 to 4 ha, with yields as low as 0.82 tons $\mathrm{ha}^{-1}$, the use of fungicides to maintain such low potential yields is costprohibitive (46). This level of production is barely sufficient to meet family food needs (2). Production surpluses rarely occur, and the lack of a market infrastructure for the small-scale farmer greatly inhibits the sale of grain to supplement family incomes (59). In Africa as a whole, maize is almost exclusively produced by small-scale farmers under circumstances similar to those described for subsistence farmers in South Africa. Of concern is the fact that pathological expertise and resources are very limited in Africa, and as a result, some nations have been slow to recognize gray leaf spot as a potential threat to food production.

The sudden appearance of gray leaf spot and the subsequent rapid spread of the pathogen throughout South Africa have led to speculation about the origin of the pathogen. C. zeae-maydis may have entered the country with imported breeding material, but this is unlikely as there is no record of the pathogen being seedborne $(40,51)$. A more plausible explanation is that infested maize residue accompanying maize imported from the United States was the original source of $C$. zeae-maydis inoculum (73). Maize imports were necessitated by severe droughts that prevailed during the early to mid-1980s in South Africa $(42,72)$.

Large-scale commercial farmers. Because of the intensive management required for this type of farming, farmers can often afford to utilize a holistic gray leaf spot management program, provided maize production remains profitable. The management of gray leaf spot relies primarily on the use of resistant hybrids, crop rotations, tillage practices, and if need be, the use of foliar-applied fungicides $(36,61,77)$.

Small-scale farmers. Traditionally, small-scale farmers have very limited resources or none at all. The only viable management tactic available to farmers would be to plant resistant hybrids. However, developing maize hybrids with acceptable levels of resistance to gray leaf spot is typically a very slow process in developing countries (42). The fact that low soil fertility has been observed to re- duce gray leaf spot severity may provide some limited benefit to small-scale farmers, who usually cultivate maize under low-fertility conditions (73). However, this means that progressive small-scale farmers who apply manure or fertilizers to increase maize yields may place themselves at greater risk from gray leaf spot.

In southern Africa, the cultural practice of waiting to harvest the maize crop until it is fully dry may inadvertently enhance pathogen movement. Mature, partially harvested maize crops are often left standing in fields until shortly before a new crop is planted. Wind and mini-cyclones (dust devils) that occur during dry-down may help to facilitate short- and long-distance dissemination of infested maize leaf residue to maize production areas previously unaffected by gray leaf spot (73).

\section{Disease Cycle}

C. zeae-maydis is known to infect only maize (64), and the pathogen is not reported to be seedborne $(40,51)$. Like many other fungal foliar pathogens of maize, $C$. zeae-maydis is a poor food-base competitor in the soil and is better able to survive intercrop periods within infested maize crop residue present on the soil surface $(16,49,61,64)$. Following periods of high humidity in early spring, the fungus produces spores (conidia) within infested crop residue (Fig. 5). Spores are then wind-disseminated to newly planted maize crops Lower leaves are usually the sites of primary infection in the developing canopy. Under favorable environmental conditions, lesions resulting from initial infections produce spores that are wind- or rain splash-disseminated to the upper leaves. The pathogen has the potential to sporulate profusely, and lesion numbers can rapidly increase on developing leaves higher in the canopy (32). During unfavorable conditions (hot, dry weather), the fungus can remain dormant and then resume rapid development as soon as weather conditions are favorable $(31,70)$. Under prolonged favorable conditions, and especially after the canopy has closed, developing lesions may coalesce, resulting in extensive blighting and necrosis of leaf tissue $(31,61,73)$.

In general, gray leaf spot may cause only light damage to the maize crop in the first season following introduction of the pathogen into the field. However, significant losses can occur in the first season if (i) sufficient infested crop residue is disseminated by wind to previously diseasefree crops, and (ii) environmental conditions are highly favorable for disease development. Under these circumstances, lesions often first appear on the middle to upper part of the maize canopy, especially if initial infections occur late in the season. Even if yield losses do not occur in the first year of infection, infested crop residue that remains on the soil surface during the intercrop period provides an epidemiologi- 
cally important local source of inoculum to initiate new gray leaf spot epidemics in subsequent maize crops. If environmental conditions are favorable for disease development in subsequent seasons, initial inoculum arising from infested crop residue can pose a serious threat to maize production.

\section{Impact on Yield}

Losses associated with gray leaf spot occur when photosynthetic tissue is rendered nonfunctional due to lesions and/or the blighting of entire leaves. The blighting and premature death of leaves severely limits radiation interception as well as the production and translocation of photosynthate to developing kernels. This is especially true for the upper eight or nine leaves, which contribute 75 to $90 \%$ of the photosynthate for grainfill (1). Leaves of susceptible hybrids or inbreds may become severely blighted or killed as early as 30 days prior to physiological maturity $(31,73)$. To quantify the impact of gray leaf spot epidemics on yield, several reference points for yield need to be operationally defined and measured (47). Attainable yield is the site-specific yield obtained for a specific location, growing season, and maize genotype, when all plant protection tactics available are used to alleviate (as much as possible) the injury caused by a specific biotic pest (in this case, C. zeaemaydis). In the maize-gray leaf spot pathosystem, attainable yield can be operationally defined as the yield obtained using the most effective fungicide treatment in a trial. Actual yield is the yield achieved when producers utilize the disease and crop management practices currently recommended for a crop or cropping system and can be operationally defined as the yield obtained from untreated plots (since fungicides are not routinely used in hybrid corn production). Percent yield loss is defined as the difference between attainable yield and actual yield/attainable yield $\times 100$ (47). Using this definition to quantify the yield losses caused by gray leaf spot, Hilty et al. (28) reported an average grain yield loss of $2.5 \%$ in Tennessee for five hybrids in 1977 after a single protectant fungicide spray was applied to maize. In Pennsylvania, Ayers et al. (4) reported grain yield increases of $20 \%$ following fungicide treatment.

Yield loss data that document the impact of gray leaf spot epidemics on attainable yield, actual yield, and percent yield loss in Iowa, Virginia, and Cedara, South Africa, are shown in Table 1. Field experiments involving protectant and systemic fungicides conducted from 1989 to 1998 resulted in grain yield increases of 24 to $69 \%$ and 11 to $44 \%$ in Virginia and Iowa, respectively (Table 1) $(11,31,62,63,65,66,67)$. These data exemplify the fact that although there are location, hybrid, and seasonal effects, yield losses due to gray leaf spot are substantial.

The components of yield most affected by gray leaf spot epidemics are (i) number of kernels per ear, and (ii) kernel size (often measured as the weight of 300 or 500 kernels). The effect of weekly applications of fungicide (chlorothalonil) on kernel number per ear and kernel size for hybrid PB3378 grown in Crawfordsville, Iowa, in 1992 is shown in Figure 6. The two large ears on the left were harvested from plots treated with fungicide, while the two smaller ears on the right were harvested from untreated plots (31). The fact that the ears harvested from the untreated plots are smaller and that many kernels at the distal end of the ears from untreated maize plots did not fill (produce kernels) show that gray leaf spot negatively impacts on the number of kernels per ear. Carter and Stromberg (11), Stromberg and Carter (63), and Stromberg and Flinchum $(65,67)$ showed that reduction in kernel size accounted for 35.3 to $41.4 \%$ of the total reduction in grain yield per plot, indicating that the yield component most affected by gray leaf spot (for Hybrid PB3320) was kernel number per ear.

The relationship between gray leaf spot disease severity and yield has been quantified by researchers in Iowa, Africa, and Virginia. In Iowa, Nutter and Jenco inoculated four maize hybrids at different stages of crop development to obtain gray leaf spot epidemics of varying intensities (43). Disease severity, assessed on the middle third of the plant (leaves 6 to 10) at growth stage 7.0 (late dough stage), explained up to $90 \%$ of the variation in yield. For each $1 \%$ increase in disease severity at growth stage 7.0 , yield was reduced by $47.6 \mathrm{~kg} / \mathrm{ha}$ in one maize hybrid and by $35.7 \mathrm{~kg} / \mathrm{ha}$ in a moderately tolerant hybrid (higher relative yield in response to similar disease levels) (Fig. 7). It needs to be pointed out that these yield loss equations may underestimate losses due to gray leaf spot, as maize

Table 1. Effect of gray leaf spot epidemics on attainable yield ${ }^{\mathrm{a}}$, actual yield ${ }^{\mathrm{b}}$, and percentage yield $\operatorname{loss}^{\mathrm{c}}$ in maize in Iowa, Virginia, and Cedara, South Africa

\begin{tabular}{|c|c|c|c|c|c|}
\hline \multirow[b]{2}{*}{ Location $^{\mathrm{d}}$} & \multirow[b]{2}{*}{ Hybrid } & \multirow[b]{2}{*}{ Season } & \multicolumn{2}{|c|}{ Yield (kg/ha) } & \multirow[b]{2}{*}{ Percent yield loss } \\
\hline & & & Attainable & Actual & \\
\hline Ames & LH119/51 & 1991 & 12,819 & 10,949 & 14.6 \\
\hline Crawfordsville & LH119/51 & 1991 & 7,302 & 6,499 & 11.0 \\
\hline Ames & LH119/51 & 1992 & 11,067 & 7,889 & 28.7 \\
\hline Crawfordsville & LH119/51 & 1992 & 9,807 & 7,537 & 23.1 \\
\hline West Des Moines & LH119/51 & 1992 & 11,278 & 9,147 & 18.9 \\
\hline Ames & PB3378 & 1991 & 11,402 & 7,298 & 36.0 \\
\hline Crawfordsville & PB3378 & 1991 & 7,966 & 6,583 & 17.4 \\
\hline Ames & PB3378 & 1992 & 9,964 & 6,095 & 38.8 \\
\hline Crawfordsville & PB3378 & 1992 & 8,864 & 4,995 & 43.6 \\
\hline West Des Moines & PB3378 & 1992 & 8,713 & 6,452 & 25.9 \\
\hline Montgomery & PB3320 & 1989 & 7,748 & 4,722 & 39.0 \\
\hline Montgomery & PB3320 & 1990 & 8,233 & 6,026 & 26.8 \\
\hline Montgomery & PB3320 & 1991 & 7,594 & 3,423 & 54.9 \\
\hline Montgomery & PB3320 & 1992 & 10,344 & 3,215 & 68.9 \\
\hline Montgomery & PB3394 & 1997 & 11,259 & 7,190 & 36.1 \\
\hline Montgomery & PB3394 & 1998 & 12,248 & 9,268 & 24.3 \\
\hline Cedara, S.A. & PAN6480 & $1995-96$ & 8,750 & 5,251 & 40.0 \\
\hline Cedara, S.A. & PAN6480 & $1996-97$ & 8,950 & 5,417 & 39.5 \\
\hline Cedara, S.A. & PAN6480 & $1997-98$ & 8,300 & 5,908 & 28.8 \\
\hline
\end{tabular}


plots were hand-harvested, not machineharvested, in these experiments (31).

Ward et al. (77,78) and Nowell (42) have reported grain yield losses of up to $67 \%$ in fungicide efficacy trials conducted in South Africa using gray leaf spot-susceptible hybrids. Grain yields were reduced by 41.7 to $43.3 \mathrm{~kg} / \mathrm{ha}$ for each $1 \%$ increase in disease severity when maize hybrids were evaluated for disease resistance to gray leaf spot at GS 10 over the 1992-93 and 1993-94 growing seasons in Cedara, South Africa (Fig. 8) (75).

Additional losses due to gray leaf spot occur when photosynthate is diverted from the stalk and roots, which then may predispose these tissues to stalk and root rots resulting in stalk lodging (Fig. 9) (19,55). Thus, losses may occur from the combined effects of C. zeae-maydis on the reduction in grain yield and an increase in stalk lodging. Moreover, losses due to lodging are often worse when maize is mechanivested fields.

Using a 1 to 5 disease index, Stromberg and Donahue (Virginia) showed that for each one-unit increase in the index, grain maturing hybrids, by $0.7 \mathrm{t} \mathrm{ha}^{-1}$ in midseason hybrids, and by $0.1 \mathrm{t} \mathrm{ha}^{-1}$ in early-maturing hybrids (64). Devastating impacts due to gray leaf spot have previously been reported by Roane et al. (55), Latterell and Rossi (34), and Smith (60).

In hybrid evaluation trials conducted in South Africa, yield losses up to 50\% have occurred in hybrids with moderate resistance, as opposed to $65 \%$ yield reductions in susceptible hybrids (79). In seasons less conducive to gray leaf spot disease development, yield losses in susceptible and moderately resistant hybrids were 38 and $20 \%$, respectively $(42,75)$. Clearly, gray leaf spot has the potential to significantly cally harvested, as opposed to hand-haryields were reduced by $1.06 \mathrm{t} \mathrm{ha}^{-1}$ in late-

reduce grain yields of maize, and the risk of yield loss is greatly influenced by seasonal environments.

\section{Epidemiology}

The absolute rate of change of gray leaf spot disease severity with respect to time is often best described by the logistic model in which the absolute rate of disease increase $(d y / d t)$ is a function of ry $(1-y)$ $(31,43,44)$. Thus, the rate of disease development of gray leaf spot epidemics is driven by three factors that interact in time and space: (i) the initial amount of inoculum or disease $(y)$, (ii) the rate of withinseason pathogen reproduction $(r)$, and (iii) the proportion of healthy tissue remaining to be infected $(1-y)$. It follows that the higher the initial level of inoculum (or present level of disease), the faster gray leaf spot development will occur with respect to time. No doubt the increased adoption of reduced tillage systems has increased initial inoculum by allowing a greater proportion of the pathogen population to survive intercrop periods within infested maize residue on the soil surface. Epidemics will also progress faster when environmental conditions (temperature, frequent and prolonged periods of high relative humidity) are favorable for pathogen reproduction. Moreover, since most of the maize hybrids presently grown within the U.S. Corn Belt range from very susceptible to moderately susceptible to $C$. zeae-maydis, these hybrids have little or no effect on reducing the rate of gray leaf spot development. The environmental component is extremely important in determining the amount of injury that will occur by the time the crop reaches maturity. Even when initial inoculum is not limiting, gray leaf spot severity may not reach damaging levels when the environment is unfavorable for disease development $(18,31,75)$.

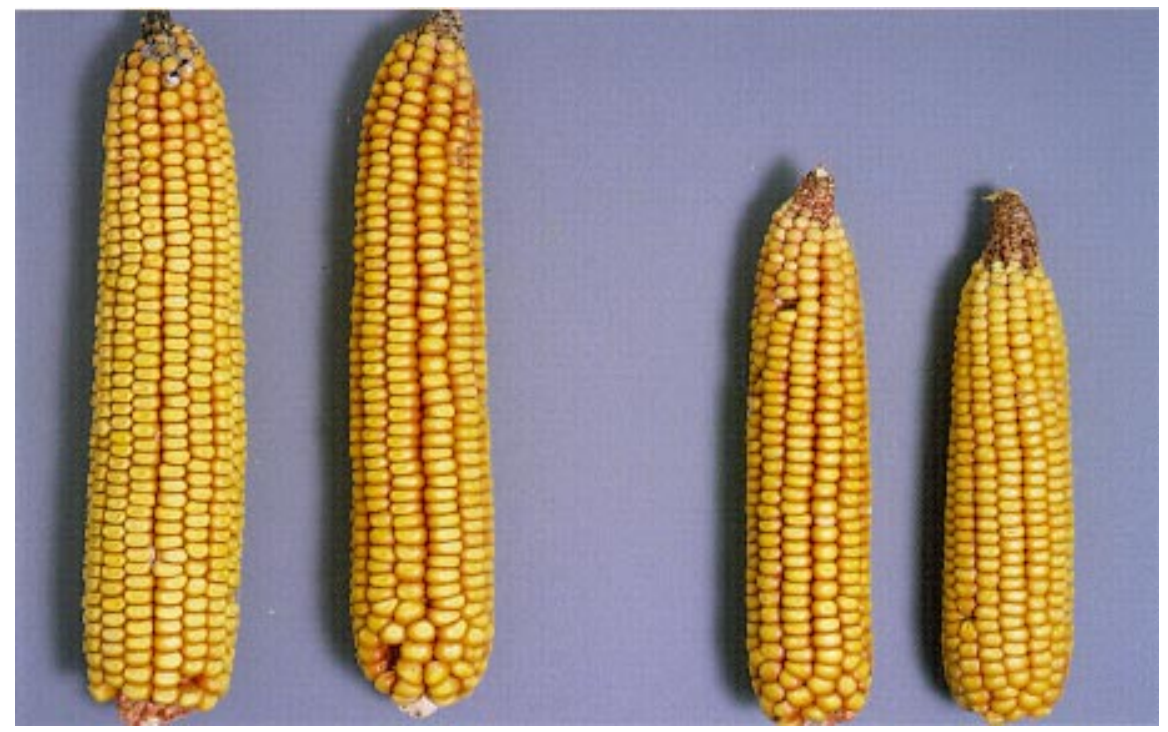

Fig. 6. Effect of fungicides on maize ears harvested from fungicide-treated plots (large ears on left) compared with ears harvested from untreated plots.
As stated above, gray leaf spot is highly dependent upon favorable weather conditions. The pathogen has been reported to require frequent and prolonged periods of high relative humidity to complete the infection process $(32,34,70)$. Several studies have shown that environmental factors have a tremendous impact on the rate of within-season gray leaf spot disease development. In Ohio, de Nazareno et al. (18) reported that the rate of gray leaf spot progress $(r)$ ranged from 0.13 to 0.17 logits per day during growing seasons favorable for disease development and 0.02 to 0.06 logits per day during seasons less favorable for gray leaf spot development. In Iowa, Nutter and Stromberg (46) obtained somewhat higher estimates of disease increase, with rates of disease development ranging
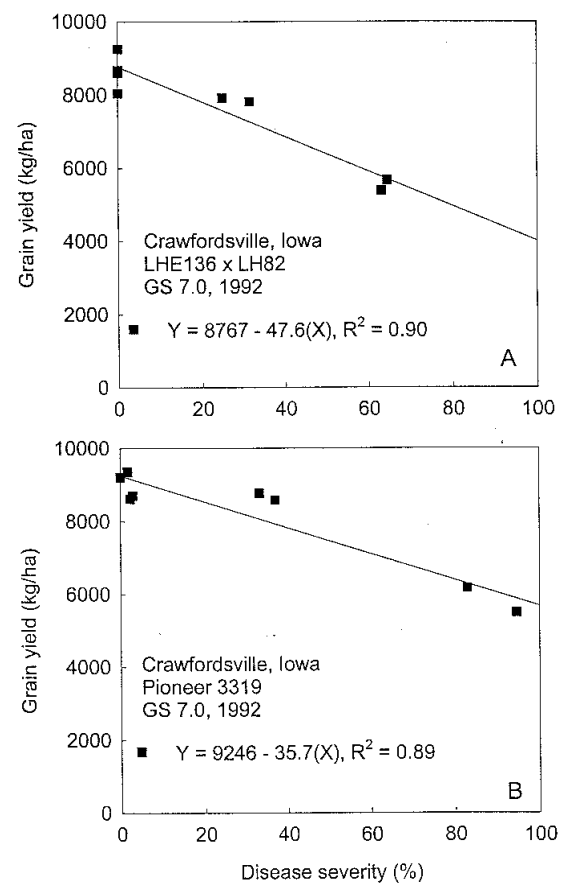

Fig. 7. Effect of gray leaf spot disease severity assessed at growth stage 7.0 on maize yields for $(A)$ susceptible hybrid and (B) moderately tolerant hybrid grown in Crawfordsville, lowa, in $1993(31,43)$.

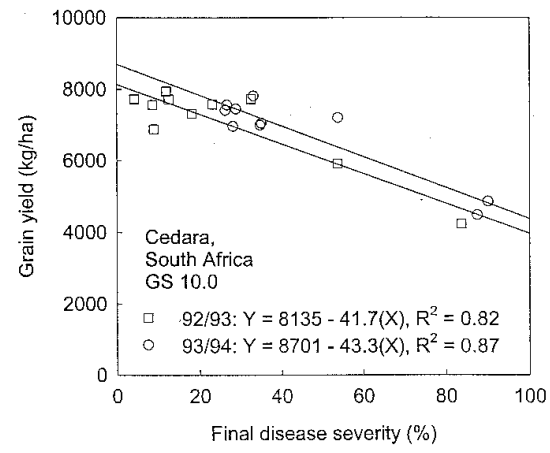

Fig. 8. Effect of final gray leaf spot severity on grain yields of maize hybrids over the 1992-93 and 1993-94 growing seasons in Cedara, South Africa. 
from 0.07 in 1991 (moderately unfavorable) to 0.28 logits per day in 1992 (extremely favorable). In Virginia, rates of gray leaf spot disease development ranged from 0.09 to 0.16 logits per day (46). In fungicide efficacy trials conducted at the Cedara Agricultural Development Institute near Pietermaritzburg, South Africa, Ward et al. (76) reported apparent infection rates of up to 0.16 logits per day during the 1991-92 season (highly favorable) and up to 0.10 logits per day (moderately favorable) during the 1992-93 season. Higher apparent infection rates in moderately favorable years coupled with longer growing seasons helps to explain why disease severities are generally higher by the end of the growing season in Africa compared with the United States (46).

Several researchers have quantified the effects of environmental factors on specific disease rate component processes. Beckman and Payne (6) reported that spores of C. zeae-maydis germinated after $24 \mathrm{~h}$ at 22 to $30^{\circ} \mathrm{C}$ when inoculated plants were exposed to $12 \mathrm{~h}$ of mist daily. They also observed that the presence of free water on the upper leaf surfaces greatly reduced germ tube growth toward stomata (thus lowering infection efficiency), whereas increased germ tube elongation toward stomata was observed on leaf surfaces where no free water accumulated. Thorson and Martinson (70) found that germ tube elongation did not occur when germlings were subjected to relative humidities below $95 \%$. In a maize field, the microclimate that occurs 1 to $2 \mathrm{~mm}$ above the leaf lamina (the site of spore deposition, germination, and infection) may well be saturated for long periods of time, even when the relative humidity in the canopy is less than $95 \%$, thus providing conditions favorable for infection and lesion development (70). Latterell and Rossi (34) noted that C. zeae- maydis can survive adverse conditions once the germination and infection processes have begun. Thorson and Martinson (70) also found that once spores have germinated, germlings are able to tolerate a wide range of alternating high and low relative humidity periods. Beckman and Payne (6) reported that periods of high relative humidity did not have to be continuous for infection to occur, since developing infections could remain quiescent until favorable relative humidity conditions resumed.

Beckman and Payne (6) observed that abundant appressoria formed over host stomata on the lower leaf surfaces 4 to 5 days after inoculation, with penetration occurring 6 to 7 days after inoculation. In greenhouse studies, chlorotic, dotlike lesions were first observed 9 days after inoculation. The time from inoculation to appearance of the first lesions is one definition of incubation period $(6,7)$; however, the time from inoculation to $50 \%$ lesion appearance, an operational definition often used to characterize the incubation period of a population of spores (45), has not been reported. Following appressorial formation, C. zeae-maydis developed stromata within substomatal cavities, which then gave rise to numerous spores 16 to 21 days after inoculation (6).

Stromata that form within the substomatal cavities can survive extensive dry periods and resume colonization of substomatal cavities and/or sporulation whenever environmental conditions are favorable (61). The effect of fluctuating relative humidities on these processes may account for much of the variability in the length of time from inoculation to the time that lesions produce spores (latent period) (46). In addition to the effects of relative humidity, maize genotypes can also greatly affect the length of the latent period.

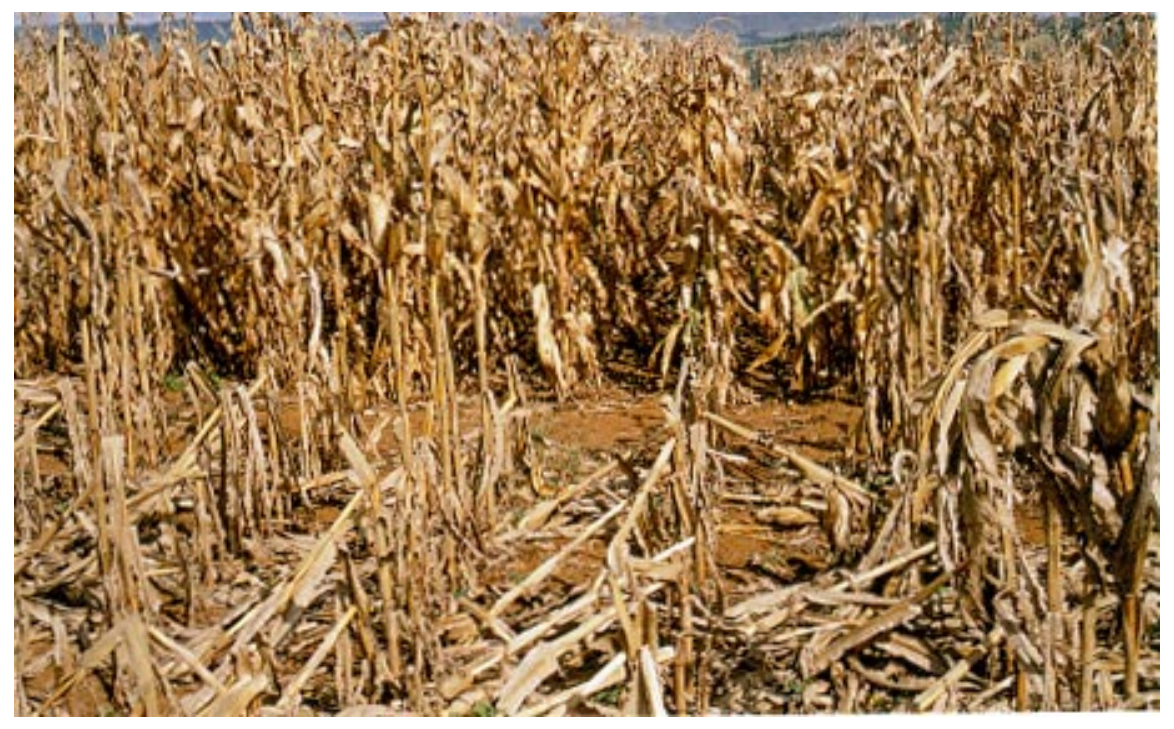

Fig. 9. Gray leaf spot predisposes maize to stalk rots, resulting in severe lodging (foreground) compared with fungicide-treated maize (background). Cedara, South Africa.

Ringer and Grybanskas (52) reported that the latent period of $C$. zeae-maydis in the field was approximately 14 days for susceptible hybrids and 22 days for moderately resistant hybrids. The occurrence of fewer and/or shorter periods of high humidity early in the growing season may also explain the slower rate of early-season disease development that has been observed in some geographical areas. For example, Ringer and Grybanskas reported that early-season rains resulted in favorable relative humidity conditions that led to a higher frequency of early-season lesions (52). Field observations in South Africa indicate that even when relative humidity is favorable for pathogen development, fewer primary lesions develop (and lateseason disease severity is less) when mean daily temperatures fall below $20^{\circ} \mathrm{C}$ (73). This is especially true where initial inoculum (infested residue) is relatively low. With increasing levels of initial inoculum, however, significant levels of disease can still develop over a fairly wide range of temperatures.

In general, later maturing hybrids are at greater risk from gray leaf spot than earlyto midseason hybrids because (i) the growing season is longer (absolute rate of disease increase, $d y / d t$, occurs over a longer period of time), and (ii) higher disease severity levels that reduce radiation interception are more likely to coincide with the critical period of grainfill in latematuring genotypes (64). This is a particularly important factor in Africa, where predominantly long-season hybrids generally require longer periods to reach physiological maturity-30 to 70 days longer-than in the United States (73). In Africa, initial gray leaf spot lesions typically appear well before anthesis, as opposed to at anthesis or later throughout most of the United States. In some areas of Virginia, however, sporulating lesions have also been observed to occur 2 to 3 weeks before anthesis (E. L. Stromberg, unpublished data). The appearance of lesions earlier in the growing season in Africa allows host and pathogen populations to interact over a longer period of time. This would explain why disease severities are generally higher in South Africa even though higher rates of disease development have been recorded in Iowa (46). Increased lesion numbers earlier in the season, followed by conditions favoring secondary spread, are more likely to result in damaging levels of gray leaf spot during the critical period of grain fill (46). Thus, it is not surprising that $C$. zeae-maydis has generally caused greater reductions in grain yields in Africa than in the United States.

\section{Disease Management}

Influence of infested maize crop residue. Since 1989, the percentage of maize fields under reduced tillage $(>15 \%$ maize residue) has remained consistently high in 
Virginia, ranging from $69.1 \%$ (1989) to $78.6 \%$ (1995) (Fig. 10) (Conservation Technology Information Center, West Lafayette, IN). During the same period in Iowa, however, the percentage of maize fields in reduced tillage increased from 55.1 to $77.9 \%$, and gray leaf spot prevalence (percent field basis) in Iowa has increased from $10 \%$ in 1983 to $95 \%$ in 1997 (Fig. 11). Several researchers have shown that any tillage practice leaving infested maize residue on the soil surface favors gray leaf spot development. This is because the absolute rate of disease development increases as the amount of infested crop residue increases $(17,48,76)$. Without question, the increase in the number of maize fields managed under some form of reduced tillage has substantially increased the volume of infested maize residue. Epidemiologically, infested crop residue is the most important within-field source of $C$. zeae-maydis inoculum $(17,61)$.

In a 2-year study conducted in Ohio, de Nazareno et al. (16) detected sporulation of C. zeae-maydis in May from infested maize leaf and sheath pieces (residue) placed on the soil surface the previous December. Sporulation was generally higher on lesions from leaves (up to 5,431 spores per $\mathrm{mm}^{2}$ of lesion) than from sheaths (up to 105 spores produced per $\mathrm{mm}^{2}$ of lesion). However, when infested maize residue was buried 5 to $10 \mathrm{~cm}$ below the surface in December, sporulation was not detected the following May. Payne and Waldron (49) found that C. zeae-maydis survived from November 1979 until May 1980 in infested residue placed on the soil surface in North Carolina; however, $C$. zeae-maydis did not survive beyond January when infested maize residue was buried $15 \mathrm{~cm}$ below the soil surface.

C. zeae-maydis spores are disseminated primarily by wind, although rain-splash dispersal can also occur $(31,32,34,55)$. Payne et al. (48) found that the mean number of airborne spores was significantly

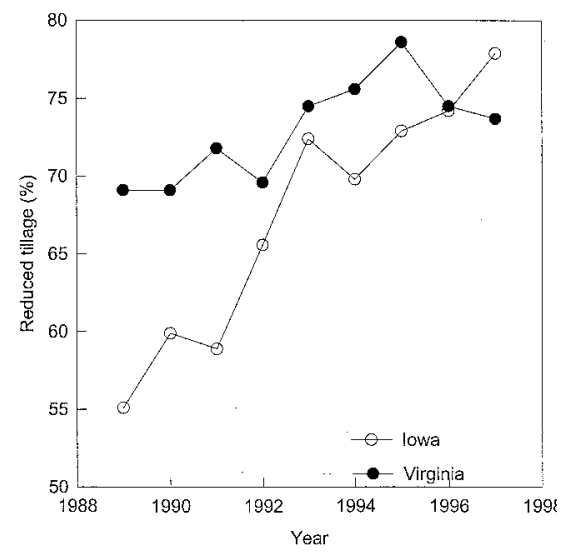

Fig. 10. Percentage of maize fields in reduced tillage in Virginia and lowa, 1989 to 1997. greater in no-tillage plots than in plots receiving some form of tillage. They also reported that airborne spores of C. zeaemaydis were trapped as early as 23 May 1984 (the first day that spore traps were placed in the field); yet lesions did not appear until 2 weeks before silking. In Iowa, F. W. Nutter (unpublished data) trapped spores of C. zeae-maydis as early as 18 April 1995, which was approximately 1 to 4 weeks before maize was planted in Iowa that year.

Rupe et al. (56) hypothesized that disease onset and progress are influenced by physiological age of the plant, as initial symptoms typically appear at or near anthesis. Other U.S. researchers have observed a similar seasonal periodicity regarding the initial appearance of lesions $(18,31,48)$. In South Africa, however, J. M. J. Ward and F. W. Nutter (unpublished data) have not observed a seasonal periodicity in the timing of symptom appearance, and initial lesions are often observed on young seedlings.

Because C. zeae-maydis produces relatively large spores, within-field dispersal gradients are steep. In Iowa, Nutter et al. (44) determined the number of lesions per leaf on leaves below and above the ear leaf with respect to distance from an inoculum source and found that disease gradients tended to flatten approximately 5 to $6 \mathrm{~m}$ from the inoculum source. Nutter also noted that disease gradient curves had a long tail (Fig. 12A) because some lesions were present on plants $50 \mathrm{~m}$ from the source (data not shown in figure). This tail for gray leaf spot disease gradients indicates that $C$. zeae-maydis spores have the potential to escape the maize canopy and that spores could travel substantial distances. In Ohio, de Nazareno obtained very similar gradients by assessing the number of lesions on the third leaf below and above the ear leaf with respect to distance from an inoculum source (18). Again, these researchers found that disease gradients flattened just 5 to $6 \mathrm{~m}$ from the inoculum source and that some lesions

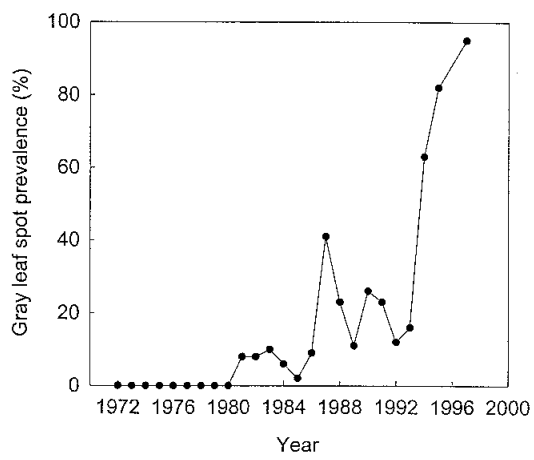

Fig. 11. Increase in prevalence of gray leaf spot in maize in lowa from 1972 to 1997. Gray leaf spot was not detected in surveys prior to 1981. were found at much greater distances from the source. For both the Iowa and the Ohio data, gray leaf spot disease gradients were best fit by the logit-linear model proposed by Minogue and Fry (41) (Fig. 12B).

Although within-field presence of $C$. zeae-maydis-infested maize residue substantially increases the risk of gray leaf spot epidemics and yield losses, the nearuniversal use of reduced tillage in today's major maize production areas has increased the probability that neighboring maize fields could also be epidemiologically important sources of gray leaf spot inoculum. C. zeae-maydis spores (and infested residue) are primarily dispersed by wind, and several studies have been conducted to determine the seasonal $(32,48,49)$ and diurnal $(31,32)$ periodicities of C. zeae-maydis spore dispersal. Assuming (i) an average terminal velocity of 2.2 $\mathrm{cm} / \mathrm{s}$ for C. zeae-maydis spores (based on an average spore size), (ii) a coefficient of mass exchange of 10 (mixing of spores in the atmosphere 1 to $10 \mathrm{~m}$ above the crop) or 50 (mixing of spores 10 to $100 \mathrm{~m}$ above the crop), and (iii) that spores of C. zeaemaydis are able to escape from the maize canopy into the atmosphere (5), the estimated flight distances for $C$. zeae-maydis spores can range from $0.1 \mathrm{~km}$ to more than $40 \mathrm{~km}$ as wind speed increases from 1 to $10 \mathrm{~m} / \mathrm{s}(0.477 \mathrm{~m} / \mathrm{s}=1.0 \mathrm{mph})$ (Fig. 13). Thus, the physical laws governing spore dispersal (spore size, wind speed, and
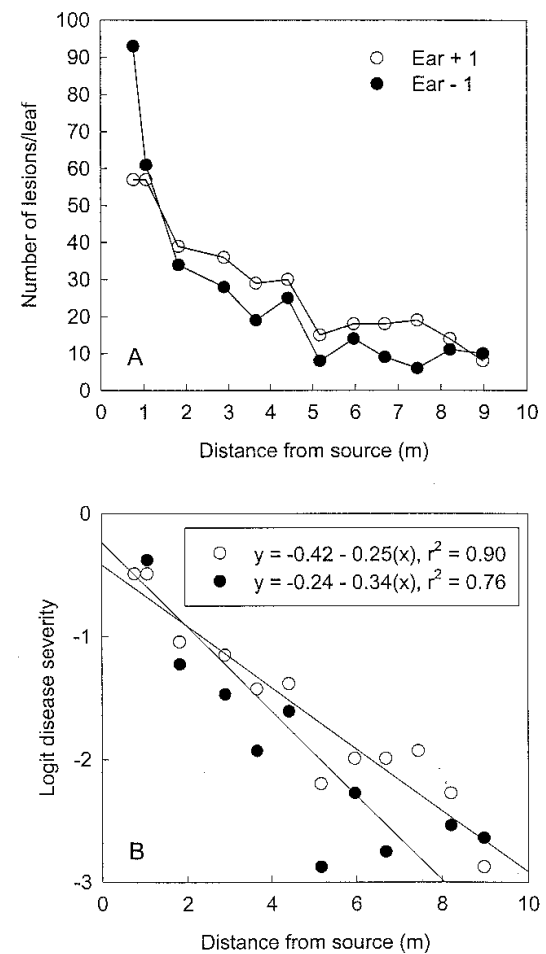

Fig. 12. (A) Disease gradients of Cercospora zeae-maydis measured by number of lesions per maize leaf with respect to distance from inoculum source in Ames, lowa, in 1993. (B) Gray leaf spot disease gradients fit by the logit-linear model. 
height of vertical mixing of the atmosphere above the crop) support the field observations concerning the presence of a long spore dispersal tail. Because these flight distances are based on calculations using an average spore size for $C$. zeae-maydis (spore size ranges from 40 to $165 \mu \mathrm{m}$ by 4 to $9 \mu \mathrm{m}$ ), smaller spores will have lower terminal velocities and thus longer flight distances than those depicted in Figure 13. Conversely, larger sized spores will have higher terminal velocities and shorter flight distances than those depicted in Figure 13. The wind speeds above maize canopies in the U.S. Midwest often exceed $64 \mathrm{~km} / \mathrm{h}$ (40 mph) during wind gusts associated with summer rainstorms. In addition to wind dispersal of $C$. zeae-maydis spores, infested maize residue can also be disseminated great distances during such storms, especially late in the growing season during the dry-down period. Thus, farmer efforts to reduce initial inoculum via crop protection and/or conventional tillage systems may not realize their full epidemiological benefits if neighboring farmers are utilizing some form of reduced tillage, because inoculum originating from neighboring reduced-tillage fields could reduce the effectiveness of cultural practices aimed at within-field management of C. zeae-maydis initial inoculum.

Although several studies have shown that even a single year of crop rotation can significantly reduce the initial level of $C$. zeae-maydis inoculum, it normally takes several years of rotation to reduce inoculum to levels achieved by deep plowing $(29,34,50,61)$. In addition to reducing initial inoculum, crop rotation provides additional benefits by improving soil quality and conserving soil water content. In spite of these benefits, crop rotation may not be economically attractive to producers when alternative rotation crops reduce net farm income. Furthermore, in regions where extensive areas are under reduced tillage, maize grown in rotation may still be at risk as a result of windblown inoculum originating from infested maize residue in nearby fields (17). Perkins et al. (50) and

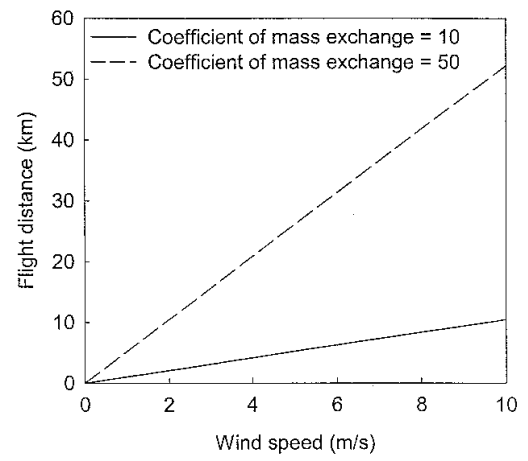

Fig. 13. Estimated flight distances for Cercospora zeae-maydis spores as affected by the coefficient of mass exchange and wind speed.
Lipps et al. (37) stated that although deep plowing and crop rotation both reduce initial inoculum, these tactics may not be sufficient to successfully manage gray leaf spot in high-risk areas where the pathogen is largely endemic. This certainly is the case in the mid-Atlantic region of the United States (particularly in Maryland and Virginia) and in KwaZulu-Natal, South Africa, where infested maize residues are easily recognizable on the soil surface in adjacent farmer fields. In these situations, little difference has been observed in the severity of gray leaf spot among the different types of tillage and crop rotation systems used $(52,61,77)$. This is as a result of significant amounts of primary inoculum being produced locally (and regionally) to continually infect neighboring maize crops $(31,52,61,78)$.

The most damaging gray leaf spot epidemics have been observed in fields where reduced tillage practices permit the pathogen to become endemic (50). When maize is planted into no-till fields with infested maize residues remaining on the soil surface and environmental conditions are favorable for gray leaf spot development, epidemics usually progress faster and reach more damaging levels than in maize planted into conventionally tilled fields where infested residues are either absent or greatly reduced $(16,17,49,61,73)$. de Nazareno et al. found a significant, positive association between the amount of maize residue on the soil surface and disease severity (16). Thus, tillage operations aimed at reducing the amount of initial inoculum that carries over from the previous season's crop residue have been recommended as a means of managing gray leaf spot $(16,29,38,49)$.

The impact of infested-residue levels on epidemic development is less pronounced under dry weather conditions than during seasons with prolonged periods of high relative humidity. In Southern Africa, reduced tillage helps conserve soil moisture, which significantly reduces production costs. These benefits, however, may be negated by the presence of infested surface crop residue, which significantly increases the risk of producers experiencing damaging gray leaf spot epidemics $(42,73,79)$.

Because of U.S. government regulations (1985 Farm Bill) and the agronomic advantages of reduced tillage practices, it is not likely that reduced tillage practices will be set aside in order to better manage gray leaf spot. Large-scale adoption of reducedtillage practices has therefore necessitated a change in disease management strategy from one that relies solely on reducing initial inoculum to one that also reduces the rate of gray leaf spot epidemics. The use of maize hybrids with adequate levels of rate-reducing resistance, coupled with management practices that reduce initial inoculum, are both now required to effectively manage gray leaf spot. In the ab- sence of hybrids that possess acceptable levels of rate-reducing resistance, fungicides are often relied on to reduce the rate of disease development in high-yield potential cropping systems $(38,43,44)$.

Resistance, inheritance, sources of resistance, and incorporating resistance into high-yielding hybrids. Genetic resistance is the most cost-effective strategy for managing gray leaf spot, and numerous studies have been conducted to improve hybrid resistance. It is generally concluded that commonly used inbreds lack effective gray leaf spot resistance $(4,21,29,39,68)$; however, usable resistant germ plasm has been found within inbred populations, and this resistance is inherited quantitatively in an additive manner $(14,16,20)$. In the United States, research to improve resistance to gray leaf spot has been conducted in Delaware (71), Pennsylvania $(4,21,29)$, North Carolina $(9,69)$, Illinois $(14,15)$, and Virginia $(21,39)$. In contrast, South African researchers found an unexpectedly high frequency of quantitative resistance to gray leaf spot already present within commercial hybrids $(42,73,74)$. In addition to quantitative resistance, a single gene conferring qualitative resistance to gray leaf spot has been found in one maize genotype from South Africa $(26,27)$. Bubeck et al. (9) and Saghai Maroof et al. $(57,58)$ have identified quantitative trait loci (QTL) associated with gray leaf spot resistance. The use of molecular markers to assist breeders to follow the inheritance of QTLs may facilitate a more rapid transfer of gray leaf spot resistance into susceptible germ plasm without the transfer of negative agronomic characteristics (58).

Quantitative resistance to gray leaf spot has been found to impact several components of resistance, including lesion size, latent period, and sporulation $(4,14,23,30$, 36,52,57). Characteristic lesions appear later in moderately resistant hybrids (longer incubation period) (6), and sporulation may also be delayed (longer latent period) in genotypes with moderate levels of resistance to gray leaf spot (7). Ringer and Grybauskas (52) have also reported shorter latent periods for susceptible hybrids (14 to 19 days after inoculation) and longer latent periods (16 to 22 days after inoculation) for moderately resistant hybrids.

Tolerance to gray leaf spot. Disease tolerance can be defined as a relative measure of the yield response of two or more maize genotypes to increasing injury levels caused by gray leaf spot (47). A number of researchers and farmers have observed that some maize hybrids can produce higher yields than other hybrids with similar levels of gray leaf spot severity (thus satisfying the above definition of disease tolerance). Integrating the development of maize hybrids possessing tolerance to gray leaf spot into a sustainable management program may prove difficult. 
It remains unclear whether the greatest benefits in terms of disease management and yield protection will occur when a tolerant hybrid is seeded in rotation before or after a resistant maize hybrid is grown. For example, in a maize-soybean-maize rotation, growing a resistant maize hybrid first would likely result in a lower amount of initial inoculum (pathogen-infested residue) to cause disease the next maize crop, compared with seeding a tolerant maize hybrid first. This ordering (resistant maize hybrid-soybean-tolerant maize hybrid) may optimize yields in the short term, but such cropping sequences may require longer rotations before any maize hybrid should follow a tolerant maize hybrid.

Use of fungicides. Fueled by the increased use of reduced-tillage systems and the extensive planting of susceptible germ plasm, gray leaf spot pandemics in the United States and Africa continue to suppress maize yields $(38,73)$. Although efforts to improve resistance to gray leaf spot in maize hybrids and inbreds have increased dramatically in the 1990s, the planting of higher yielding hybrids rather than hybrids with effective quantitative resistance, coupled with the presence of greater levels of infested maize crop residue each year, has necessitated the use of fungicides to maintain yield potentials in many circumstances. In seed maize crops and a limited number of commercial grain crops in the United States, as well as in seed and feed maize crops in Southern Africa, fungicides are used to effectively and economically manage gray leaf spot epidemics. Although some of the registered protectant fungicides provide acceptable control, the more effective products are systemic benzimidazole and triazole fungicides $(11,42,62,65-67,73)$. More recently, strobilurin compounds have also proven to be effective $(65,67,78)$.

Soil fertility. Little research has been conducted on the effects of plant nutrition on the development of gray leaf spot in maize. Smith (60) found that the application of nitrogen significantly increased the severity of gray leaf spot, whereas Carrera and Grybauskas (10) reported that severity of gray leaf spot was not affected by increased nitrogen. Observations from field trials conducted in KwaZulu-Natal, South Africa, over three seasons support the hypothesis that gray leaf spot severity increases as the levels of nitrogen and potassium increase (73).

Plant density. In all but one study (18), reductions in plant density have been found to result in an increase in gray leaf spot severity $(10,42,53,60)$. This effect is particularly apparent on the edges of fields and in areas of poor germination and may be due to the fact that wind speed can be greatly reduced and relative humidities greatly increased in higher plant densities (42).

Irrigation. Overhead irrigation, particularly the use of center pivots, can sig- nificantly increase the rate of gray leaf spot disease development, resulting in significantly higher levels of gray leaf spot incidence and severity.

\section{The Future}

Gray leaf spot will continue to increase in importance and geographical extent in maize production regions throughout the world, particularly in the subtropical and tropical maize production regions, as well as in temperate maize production regions in China. Preventing C. zeae-maydis from becoming a severe problem by reducing initial inoculum would be the most suitable management strategy, but it is society's nature to react to problems rather than establish or maintain effective preventative measures. Changes in governmental and conservation policies have shifted the battle for gray leaf spot control in the favor of the pathogen. Once gray leaf spot is endemic within a maize production area, disease management strategies need to be adjusted accordingly. For example, prior to the occurrence of gray leaf spot in maize production areas, disease management was aimed at reducing initial inoculum, because disease management tactics such as conventional tillage and crop rotation were extremely effective in preventing leaf spot epidemics. However, once gray leaf spot becomes endemic, disease management tactics must first focus on protection by reducing the rate of gray leaf spot disease development. This can best be accomplished by the use of maize resistance and/or fungicides.

Gray leaf spot epidemics can be devastating under favorable environmental conditions; but cost-effective management tactics are available to the larger commercial producers to manage this disease. Unfortunately, many of these tactics (resistance, fungicides, residue management) are either not available or not cost-effective for adoption by small-scale subsistence farmers in the tropics and subtropics.

The most sustainable and long-term gray leaf spot management strategy will rely heavily on the development of high-yielding, locally adapted gray leaf spot-resistant hybrids that reduce the rate of within-season disease development. This long-term strategy appears to be more easily attainable in Africa, where a wider range of maize germ plasm possessing acceptable levels of quantitative resistance to gray leaf spot is more readily available to the maize seed industry $(42,77)$. Still, this germ plasm will have to be carefully screened for yield potential, yield stability, and suitability to the farmer and the consumer. The goal of developing gray leaf spot hybrids with acceptable levels of quantitative resistance may take longer and be more difficult to achieve in developed countries, where yield potential is of paramount importance and germ plasm is highly susceptible. In the short term, susceptible hybrids and cultivars will require an integrated management strategy that may necessitate the use of fungicides to protect maize crops by reducing disease rates, coupled with the use of crop rotation and residue management tactics that greatly minimize initial inoculum.

Although the use of single-gene resistance to gray leaf spot is a tempting option in the short term $(26,27)$, the deployment of this resistance strategy may, in the long term, delay the development and deployment of hybrids with acceptable levels of quantitative resistance. It is possible that advances in molecular breeding techniques, such as the incorporation of QTLs for gray leaf spot resistance, could greatly reduce the time required to obtain resistant maize hybrids with acceptable levels of quantitative (rate reducing) resistance.

The risks versus benefits of crop rotation in reducing gray leaf spot and improving soil properties need to be evaluated in each maize production area and this information passed on to maize farmers. The economics of planting alternative crops and the use of new cropping systems need to be locally evaluated. Before wide-scale adoption, new integrated disease management programs need to be proven environmentally acceptable in order to ensure the long-term sustainability of maize-based cropping systems.

In Africa, small-scale farmers, whose yield potentials are already inherently low, are at high risk of experiencing larger food shortfalls due to gray leaf spot. The effects of soil and plant nutrition on the development of gray leaf spot should be investigated under a wider range of production environments.

Systemic fungicides in the benzimidazole and triazole chemical groups are currently registered for the control of gray leaf spot in the United States and Southern Africa. Because of the large-scale use of these products, it is possible that the pathogen may develop resistance to one or both of these chemical groups. It is important that evaluation of fungicides of different chemical groups be continued so that additional fungicides may become available, should pathogen resistance become a problem. Farmers should be educated and encouraged to utilize integrated gray leaf spot management tactics and programs that will either eliminate the need for fungicides or substantially reduce their necessity.

It is important to remember that $C$. zeaemaydis is only one of many pathogens of maize. For example, another "no-till" disease of increasing importance in Southern Africa and the United States is eyespot of maize, caused by Aureobasidium zeae (22). It is vital that a holistic approach to maize disease management be undertaken to ensure that the potential negative impacts due to other previously "minor" maize pathogens are recognized early and managed effectively. 


\section{Acknowledgments}

We thank Nita Upchurch, Ames, Iowa, for drawing the disease cycle diagram (Fig. 5). Research was supported by State and Hatch Funds allocated to the Iowa Agriculture and Home Economics Experiment Station and by Pioneer HiBred International, Johnston, Iowa, and various other seed and agrochemical industries in Virginia and South Africa. Journal Paper 18244 of the Iowa Agriculture and Home Economics Experiment Station. Project 3394

\section{Literature Cited}

1. Allison, J. C. S., and Watson, D. J. 1996. The production and distribution of dry matter in maize after flowering. Ann. Bot. (London) 30:365-381.

2. Anonymous. 1996. A profile of small to medium sized farmers in Natal and KwaZulu. Cedara Report No. N/A/96/14 - KwaZulu Department of Agriculture, Private Bag X9059, Pietermaritzburg, 3200, South Africa.

3. Anonymous. 1997. Abstracts of Agricultural Statistics and Management Information, Pvt. Bag X144, Pretoria 001, South Africa.

4. Ayers, J. E., Johnson, M. W., and Hill, R. R. 1984. Identifying resistance to gray leaf spot. Pages 157-175 in: Proc. Maize Sorghum Res. Conf., 39th. Am. Seed Trade Assoc., Washington, DC.

5. Aylor, D. E. 1990. The role of intermittent wind in the dispersal of fungal pathogens. Annu. Rev. Phytopathol. 28:73-92.

6. Beckman, P. M., and Payne, G. A. 1982. External growth, penetration, and development of Cercospora zeae-maydis in corn leaves. Phytopathology 72:810-815.

7. Beckman, P. M., and Payne, G. A. 1983. Cultural techniques and conditions influencing growth and sporulation of Cercospora zeae-maydis and lesion development in corn. Phytopathology 73:286-289.

8. Boothroyd, C. W. 1964. Effect of elevation, rainfall and temperature upon the incidence of corn diseases in Costa Rica. (Abstr.) Phytopathology 54:127.

9. Bubeck, D. M., Goodman, M. M., Beavis, W. D., and Grant, D. 1993. Quantitative trait loci controlling resistance to gray leaf spot in maize. Crop Sci. 33:838-847.

10. Carrera, L. M., and Grybauskas, A. 1992. Effect of planting dates and plant density on the development of gray leaf spot of corn. (Abstr.) Phytopathology 82:718-719.

11. Carter, M. R., and Stromberg, E. L. 1992. The evaluation of foliar fungicides for the control of gray leaf spot disease on corn in Virginia, 1991. Fungic. Nematicide Tests 47:169.

12. Chupp, C. 1953. A Monograph of the Fungus Genus Cercospora. Ronald Press Co., New York.

13. CIMMYT. 1990. 1989/90 CIMMYT World Maize: Facts and trends: Realizing the potential of maize in sub-Sahara Africa. Mexico, DF, Mexico.

14. Coates, S. T., and White, D. G. 1994. Sources of resistance to gray leaf spot of corn. Plant Dis. 78:1153-1155

15. Coates, S. T., and White, D. G. 1995. Inheritance of gray leaf spot resistance in selected inbreds. Pages 195-202 in: Proc. Illinois Maize Breeders School, 31st. University of Illinois, Urbana.

16. de Nazareno, N. R. X., Lipps, P. E., and Madden, L. V. 1992. Survival of Cercospora zeaemaydis in corn residue in Ohio. Plant Dis. 76:560-563.

17. de Nazareno, N. R. X., Lipps, P. E., and Madden, L. V. 1993. Effect of levels of corn residue on the epidemiology of gray leaf spot of corn in Ohio. Plant Dis. 77:67-70.

18. de Nazareno, N. R. X., Madden, L. V., and Lipps, P. E. 1993. Characterization of gray leaf spot epidemics in maize. J. Plant Dis. Prot. 100:410-425.

19. Dodd, J. L. 1980. The role of plant stresses in development of corn stalk rots. Plant Dis. 64:533-537.

20. Donahue, P. J., Stromberg, E. L., and Myers, S. L. 1991. Inheritance of reaction to gray leaf spot in a diallel cross of 14 maize inbreds. Crop Sci. 41:926-931.

21. Elwinger, G. F., Johnson, M. W., Hill, R. R., Jr., and Ayers, J. E. 1990. Inheritance of resistance to gray leaf spot of maize. Crop Sci. 30:350-358.

22. Flett, B. C., and Nowell, D. C. 1995. First report of maize eyespot caused by Aureobasidium zeae in South Africa. Afr. Plant Prot. 1:49-50.

23. Freppon, J. T., Lipps, P. E., and Pratt, R. C. 1994. Characterization of the chlorotic lesion response by maize to Cercospora zeae-maydis. Plant Dis. 78:945-949.

24. Freppon, J. T., Pratt, R. C., and Lipps, P. E. 1996. Chlorotic lesion response of maize to Cercospora zeae-maydis and its effect of gray leaf spot disease. Phytopathology 86:733-738.

25. Garst Seeds. 1996. Garst establishes a G.L.S. standard. Garst Seeds. On-line publication, 980318.

26. Gevers, H. O., and Lake, J. K. 1994. Gray leaf spot1 - A major gene for resistance to gray leaf spot in maize. S.A. J. Sci. 90:377-380.

27. Gevers, H. O., Lake, J. K., and Hohls, T. 1994. Diallel cross analysis of resistance to gray leaf spot in maize. Plant Dis. 78:379383.

28. Hilty, J. W., Hadden, C. H., and Garden, F. T. 1979. Response of maize hybrids and inbred lines to gray leaf spot disease and the effects on yield in Tennessee. Plant Dis. Rep. 63:515518

29. Huff, C. A., Ayers, J. E., and Hill, R. R., Jr. 1988. Inheritance of resistance in corn (Zea mays) to gray leaf spot. Phytopathology 78:790-794.

30. Hyre, R. A. 1943. New records and unusual occurrence of plant diseases. Plant Dis. Rep. 27:553-554.

31. Jenco, J. H. 1995. Epidemiology of Cercospora zeae-maydis on Zea mays in Iowa. M.Sc. thesis. Iowa State University, Ames.

32. Jenco, J. H., and Nutter, F. W., Jr. 1992. Diurnal and seasonal periodicity of Cercospora zeae-maydis in Iowa. (Abstr.) Phytopathology 82:992.

33. Kingsland, G. C. 1963. Cercospora blight of maize: A case history of a local epiphytotic in South Carolina. Plant Dis. Rep. 47:724-725.

34. Latterell, F. M., and Rossi, A. E. 1983. Gray leaf spot of maize: A disease on the move. Plant Dis. 67:842-847.

35. Leonard, K. J. 1974. Foliar pathogens of maize in North Carolina. Plant Dis. Rep. 58:532-534.

36. Lipps, P. E., and Pratt, R. C. 1989. Maize hybrid evaluations for gray leaf spot. Plant Pathol. Ser. 81, Department of Plant Pathology, Agricultural Research and Development Center, Wooster, $\mathrm{OH}$

37. Lipps, P. E., Thomison, P. R., and Pratt, R. C. 1996. Reaction of maize hybrids to gray leaf spot. Pages 163-180 in: Annu. Maize Sorghum Res. Conf., 51st.

38. Lipps, P. E., White, D. G., Ayers, J. E., and Dunkle, L. D. 1998. Gray Leaf Spot of Corn: Update. A Report from NCR-25 Technical Committee on Corn and Sorghum Diseases. American Phytopathological Society. On-line publication. May feature, full report.

39. Manh, N. Q. 1977. Inheritance of resistance to gray leaf spot in maize. M.S. thesis. Virginia Polytechnic Institute and State University, Blacksburg.

40. McGee, D. C. 1988. Maize Diseases: A Reference Source for Seed Technologists. American Phytopathological Society, St. Paul, MN.
41. Minogue, K. P., and Fry, W. E. 1983. Models for the spread of disease: Model description Phytopathology 73:1168-1173.

42. Nowell, D. C. 1997. Studies on ear rot and gray leaf spot of maize in South Africa. Ph.D. thesis. University of Natal, Pietermaritzburg 3200 , South Africa.

43. Nutter, F. W., Jr., and Jenco, J. H. 1992. Development of critical-point yield loss models to estimate yield losses in corn caused by Cercospora zeae-maydis. (Abstr.) Phytopathology 82:994.

44. Nutter, F. W., Jr., Martinson, C. A., Jenco, I., and Wegulo, S. N. 1994. Epidemiological studies concerning Cercospora zeae-maydis on maize. Proc. Congr. South Afr. Soc. Plant Pathol., 32nd

45. Nutter, F. W., Jr., and Pederson, V. D. 1985. Receptivity, incubation period and lesion size as criteria for screening barley genotypes for resistance to Pyrenophora teres. Phytopathology 75:603-606.

46. Nutter, F. W., Jr., and Stromberg, E. L. 1999. Epidemiology and management of gray lea spot of corn in the U.S. (Abstr.) Phytopathology 89:S101

47. Nutter, F. W., Jr., Teng, P. S., and Royer, M. H. 1993. Terms and concepts for yield, crop loss, and disease thresholds. Plant Dis. 77:211-215.

48. Payne, G. A., Duncan, H. E., and Adkins, C. R. 1987. Influence of tillage on development of gray leaf spot and number of airborne conidia of Cercospora zeae-maydis. Plant Dis. 71:329-332.

49. Payne, G. A., and Waldron, J. K. 1983. Overwintering and spore release of Cercospora zeae-maydis in corn debris in North Carolina. Plant Dis. 67:87-89.

50. Perkins, J. M., Smith, D. R., Kinsey, J. G., and Dowden, D. C. 1995. Prevalence and control of gray leaf spot. Pages 177-185 in: Proc. Annu. Conf. Ill. Maize Breeders School 31, University of Illinois, Urbana.

51. Richardson, M. J. 1990. An Annotated List of Seed-Borne Diseases. 4th ed. Internationa Seed Testing Association, Zurich, Switzerland.

52. Ringer, C. E., and Grybauskas, A. P. 1995 Infection cycle components and disease progress of gray leaf spot on field corn. Plant Dis. 79:24-28

53. Rivera-Canales, J. M. 1993 Yield losses, chemical control, and epidemiology of fungal leaf blights on seed maize of Iowa. Ph.D. diss. Abstract microfilm order no. ISU 1993 R525. Iowa State University, Ames.

54. Roane, C. W. 1950. Observations on maize diseases in Virginia from 1947 to 1950. Plant Dis. Rep. 34:394-396.

55. Roane, C. W., Harrison, R. I., and Genter, C. F. 1974. Observations on gray leaf spot of maize in Virginia. Plant Dis. Rep. 58:456459.

56. Rupe, J. C., Siegel, M. R., and Hartman, J. R. 1982. Influence of environment and plant maturity on gray leaf spot of corn caused by Cercospora zeae-maydis. Phytopathology 72:1587-1591.

57. Saghai Maroof, M. A., van Scoyoc, S. W., Yu, Y. G., and Stromberg, E. L. 1993. Gray leaf spot disease of maize: Rating methodology and inbred line evaluation. Plant Dis. 77:583587.

58. Saghai Maroof, M. A., Zue, Y. G., Xiang, Z. X., Stromberg, E. L., and Rufener, G. K. 1996. Identification of quantitative trait loci controlling resistance to gray leaf spot disease in maize. Theor. Appl. Genet. 93:539-546.

59. Singini, R., and van Rooyen, J. 1995. Serving small-scale farmers. An evaluation of the DBSA's farmer support programmes. Development Bank of Southern Africa, Halfway House, South Africa.

60. Smith, K. L. 1989. Epidemiology of gray leaf 
spot of field maize (Zea mays L.) caused by Cercospora zeae-maydis Tehon and Daniels. Ph.D. thesis. University of Maryland, College Park.

61. Stromberg, E. L. 1986. Gray leaf spot disease of maize. Va. Co-op. Ext. Serv. Publ. 450-072. Virginia Polytechnic Institute and State University, Blacksburg.

62. Stromberg, E. L. 1990. The evaluation of foliar fungicides for the control of gray leaf spot in Virginia, 1989. Fungic. Nematicide Tests 45:200.

63. Stromberg, E. L., and Carter, M. R. 1991. Evaluation of foliar fungicides for the control of gray leaf spot disease on corn in Virginia, 1990. Fungic. Nematicide Tests 46:241

64. Stromberg, E. L., and Donahue, P. J. 1986. Hybrid performance of yield losses associated with gray leaf spot disease. Pages 92-104 in: Proc. Maize Sorghum Res. Conf., 41st. American Seed Trade Association, Washington, DC.

65. Stromberg, E. L., and Flinchum, L. E. 1993. Evaluation of foliar fungicides for the control of gray leaf spot on corn in Virginia, 1992. Fungic. Nematicide Tests 48:207.

66. Stromberg, E. L., and Flinchum, L. E. 1998. Evaluation of foliar fungicides for the control of gray leaf spot in Virginia, 1997. Fungic. Nematicide Tests 53:143-144.

67. Stromberg, E. L., and Flinchum, L. E. Evaluation of foliar fungicides for the control of gray leaf spot in Virginia, 1998. Fungic. Nematicide Tests. In press.

68. Tehon, L. R., and Daniels, E. 1925. Notes on the parasitic fungi of Illinois. Mycologia 17:240-249.

69. Thompson, D. L., Bergquist, R. R., Payne, G. A., Bowman, D. T., and Goodman, M. M. 1987. Inheritance of resistance to gray leaf spot in maize. Crop Sci. 27:243-246.

70. Thorson, P. R., and Martinson, C. A. 1993. Development and survival of Cercospora zeae-maydis germlings in different relative humidity environments. Phytopathology 83:153-157.

71. Ulrich, J. F., Hawk, J. A., and Carroll, R. B. 1990. Diallel analysis of maize inbreds to gray leaf spot. Crop Sci. 30:1198-1200.

72. Wall Street Journal. 1995. Fungal disease is threatening US. Page C1, 21 August.

73. Ward, J. M. J. 1996. Epidemiology and management of gray leaf spot: A new disease of maize in South Africa. Ph.D. thesis. University of Natal, Pietermaritzburg 3200, South Africa.

74. Ward, J. M. J., Birch E. B., and Nowell, D. C. 1993. Gray leaf spot on maize. Coordinated extension: Maize in Natal, Cedara Agricultural Development Institute, Pietermaritzburg, R.S.A.

75. Ward, J. M. J., Hohls, T., Laing, M. D., and Rijkenberg, F. H. J. 1996. Fungicide responses of maize hybrids and gray leaf spot. Eur. J. Plant Pathol. 102:765-771.

76. Ward, J. M. J. Laing, M. D., and Cairns, A. L. P. 1977. Management practices to reduce gray leaf spot of maize. Crop Sci. 37:1257-1262.

77. Ward, J. M. J., Laing, M. D., and Nowell, D. C. 1997. Chemical control of maize gray leaf spot. Crop Prot. 16:265-271.

78. Ward, J. M. J., Laing, M. D., and Rijkenberg, F. H. J. 1997. Frequency and timing of fungicide applications for the control of gray leaf spot in maize. Plant Dis. 81:41-48.

79. Ward, J. M. J., and Nowell, D. C. 1998. Integrated management for the control of maize gray leaf spot. Integr. Pest Manage. Rev. 3:112.

80. White, D. G., Lipps, P. E., and Ayers, J. E. Gray leaf spot of maize. Rep. NCR-25 Technical Comm. Maize Sorghum Dis., St. Louis, MO.
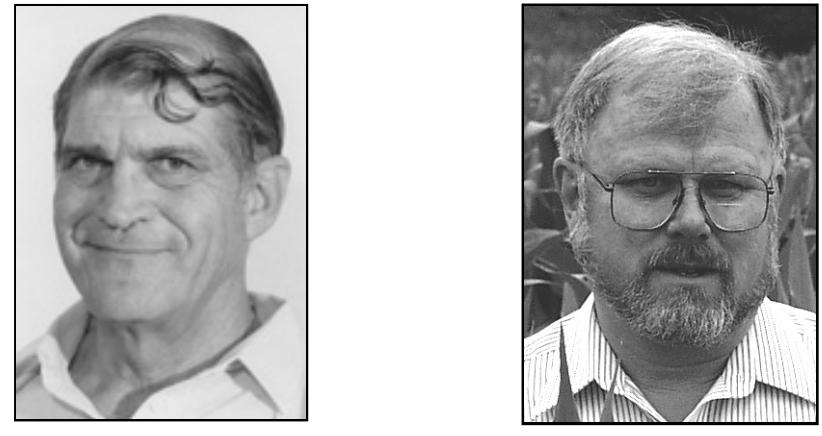

Erik L. Stromberg

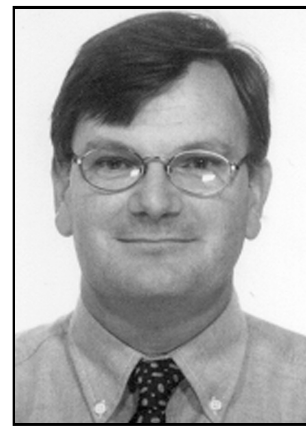

David C. Nowell

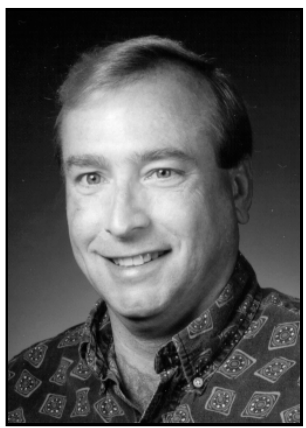

Forrest W. Nutter, Jr

Dr. Ward is a principal agricultural scientist with the KwaZulu-Natal Department of Agriculture, Cedara Research Station, near Pietermaritzburg, South Africa. He has B.Sc. (Agriculture) and Ph.D. degrees from the University of Natal. His research program focuses on the integrated management of corn diseases, with an emphasis on gray leaf spot. Dr. Ward is currently working on the development of a Cercospora zeae-maydis prediction model.

Dr. Stromberg is professor of plant pathology at Virginia Polytechnic Institute and State University (VPI\&SU). He received his B.S. in plant science in 1968 from the University of California, Riverside. After completing his Ph.D. in plant pathology from Oregon State University in 1977, he joined the USDA, APHIS, $P P Q$ disease-monitoring program at the University of Minnesota, where he held an adjunct faculty appointment in plant pathology. In 1981, he joined the Department of Plant Pathology, Physiology and Weed Science at VPI\&SU, where he was responsible for research and extension programs on diseases of field crops. His program focused on the epidemiology, genetics, and control of gray leaf spot in corn and the integrated management of diseases of winter wheat. Current research involves using molecular techniques to characterize genetic variation among Cercospora zeae-maydis isolates from maize growing areas around the world.

Dr. Nowell received his Ph.D. in plant pathology from the University of Natal. He was previously the technical services manager in the research department in PANNAR (PTY) Ltd., Graytown, South Africa. Although his responsibilities included diseases affecting a number of summer seed crops in Southern Africa, his greatest emphasis was on corn pathology. In recent years, he has worked on resistance breeding, screening, and assessment protocols to develop an integrated gray leaf spot disease management program. He is currently working in international plant protection in Rome, Italy.

Dr. Nutter is a professor of plant pathology at lowa State University with research and teaching responsibilities in plant disease epidemiology. He earned a B.Sc. in botany from the University of Maryland, an M.Sc. in botany and plant pathology from the University of New Hampshire, and a Ph.D. in plant pathology with a minor in plant breeding and statistics from North Dakota State University. Dr. Nutter was an assistant professor at the University of Georgia, Athens, from 1984 to 1990 and has been at lowa State University since 1990. His research interests are in quantitative epidemiology, benefits-risk assessment of new agricultural technologies, and modeling crop loss. He has received the Genesis Award from the American Phytopathological Society Foundation (1988) and the APS Ciba-Geigy Award (1994) in recognition of significant contributions to the knowledge of plant diseases and their control. 